\title{
MODERN TENDENCIES IN FORESTRY EDUCATION
}

\author{
BY H. W. EADES \\ Forest Products Laboratories, Vancouver
}

\section{$\mathrm{T}$} HIS article is intended to be an indirect plea for the protection of the forestry undergraduate. I would wish to save him money, and time, and disappointment. I do not wish this article to be construed as an attack upon the forestry colleges and their work. What errors they have made, or are making, were made in good faith: they have erred rather in the direction of super-excellence in their courses. But I do think that the colleges have not been, as a whole, sufficiently humanitarian in their outlook; in their anxieties to provide the best possible equipment for the young forester, and to constantly add to the number of those who might receive benefits from their intensively planned courses, they have forgotten to enquire whether or not, for that forester's own well-being, it is advisable for him to start his career with such impressive and ponderous equipment. The old Roman word for equipment was impedimenta, conveying the idea that equipment or baggage was a hindrance to troops in the field. To those who are just commencing to work in the field of forestry, too much equipment in the form of academic courses is likewise a hindrance.

Some years ago (I think I am correct in saying) three years was considered a sufficient length of time in which to obtain a bachelor's degree in Forestry. I have known foresters who, at the end of two years in a college of forestry, were considered sufficiently well trained to occupy responsible positions in various provincial forest services. Some of these latter have since advanced to a high plane in their chosen profession.

Later, the usual undergraduate course was extended to four years. Some colleges have now adopted a five-year undergraduate course, while others are considering the advisability of changing from a four to a five-year basis. There is no evidence to indicate that the movement will stop here. We may, in the not far distant future, see a seven-year course---the length of time now required for the training of a medical doctor!

I know of one college of forestry where there are some two hundred students taking the undergraduate course leading to the bachelor's degree. How many of these can reasonably expect to derive a reasonable rate of interest, from their capital investments in time and money over a term of four years? Many of them will scrape through, or "get by," in current parlance, their undergraduate years, with a degree as their goal. Once the piece of magic parchment has been secured, thinks the average undergraduate, all he has to do is to cry out with a loud voice, "Open, Sesame!," and the doors of oppor. 
tunity will thereupon open wide unto him. It is an illusion common to nearly every new graduate, and one from which he soon recovers. Research, the lumber industry, the forest services, cannot absorb the hundreds of graduates which are turned out from the forestry colleges of North America every year. There is over-production here, as, so the economists tells us, there is in most factory systems in the world today. And there was over-production in the forestry colleges years before the depression struck us.

In fairness to the young undergraduate himself the colleges should carefully examine his aptitude and his qualifications for his chosen field, forestry, before he is admitted to the course. Each college should reduce its students to the number it can reasonably expect to make a success of forestry as a career. Each applicant for admission should be carefully scrutinised as to his character, mannerisms, physical fitness, intelligence, and industry. None but the best material should be accepted. His college progress should be recapitulated at the end of his first year, and, if he does not come up to a high stand. ard, he should be advised to discontinue. A few colleges in this country, and many in Europe, have arrogated to themselves the right to reject applicants for admission, or to dismiss students if they think it advisable. State and provincial colleges cannot, of course, have as wide prerogatives in this respect as those colleges which are privately endowed. Forestry factories should be discouraged. The misguided popular clamour for equal opportunity for all is not as audible as it used to be. A five-dollar bill is useless to a man who is stranded on a desert island; and an expensive diploma is no passport through the portals of opportunity, when the doors are few and narrow and the diploma-holders are many.

Not only should the number of those passing through our forestry colleges be cut down, but our curricula are in need of revision and simplification to a considerable extent. I am opposed to the modern tendency towards educational specialization. This gospel is preached to the undergraduate be fore he enters college, and he enters with his chosen career, his special niche in forestry, all prepared beforehand in his own mind. $\mathrm{He}$ is sure that he has found a smooth, infallible, albeit long pathway leading to success. How can he be expected to know how to judge his own suitability for his specially chosen field? How many of us are able to assess accurately our own capabilities in any line of endeavour? Others are better able than ourselves to advise us of our short-comings or the efficacy of our efforts, even if we live to be an hundred and have the wisdom of Solomon. A whim, the influence of some older person, a romantic train of thought, the influence of parent or sweetheart, will sometimes start the young student along an utterly false trail. Stubbornness, fight, pigheadedness, if you like to call it that, is a characteristic common to the young adult. He scorns to "give in," when doubts come, say, in his junior year. The result is that the misguided one becomes 
a graduated misfit, a perambulating investment which will never pay a dividend.

The current vogue to prolong the undergraduate course in forestry beyond four years is to be deplored, since, I think, the extra year could very well be dispensed with, and if the undergraduate is unable to equip himself with a good foundational training within four years, he will not likely do it in five. If our forestry Solons have decided that the numbers of those graduating should be reduced, and that the only feasible way to reduction is by prolong. ing the period of training, then there is some justification for the change, but not otherwise.

I use the word "foundational" with emphasis, because that word connotes the crux of my argument herein. The undergraduate course should be essentially foundational. It should be intended to produce a man, or, shall I say, a gentleman, reliant, alert, cultured, courteous, tactful, industrious, resourceful, tractable, honest, and educated, with an open mind and open eyes. It should not be intended to produce a robot, able to answer enquiries with facility at the touch of a button.

The student should be discouraged from making any choice as to specialisation before the end of his first two and a half years at college. This period should be spent in training in foundational subjects such as chemistry, physics, mathematics, a course in biology, or two in botany and zoology, general economics, business law, accounting (necessary for anyone who is responsible for operating costs), English courses, debate and argumentation, salesmanship, letter-writing and composition, steam engines, construction and construction materials, surveying and draughting, a little geology, minerology and physiography, and a course in French or German. Subjects like forest management, silviculture, and more advanced courses in mechanical or civil engineering should be left alone during the first two and a half years. During the summer vacations of this period, in fact, during his whole course, the student should seek active work in whatever fields of forestry are open or which appeal to him. This experience will assist in stabilizing his opinions as to specialisation later on.

The reasons why a student should confine his energies, during his first two and a half years, to general subjects, are:

1. He will obtain a foundation on which to build his specialised training later.

2. He will build up a reserve fund of information on which to draw when specialised problems come up in later life.

3. If he ever attains to an executive position, he should be equipped to assess and direct the labours of others who may be specialists.

At the end of two and a half years, by careful consultation with his faculty adviser, the student should choose his remaining courses with special 
aims in view, subject, of course, to the proviso that certain courses could only be taken when preceded by necessary prerequisite courses. He should be encouraged throughout his undergraduate career to take part in college activities such as games and debates. These are important, and develop the qualities that lead to leadership.

I think the gospel of specialisation is preached too frequently in these times, and I wish to emphasize my suggestion that the training in the first two and a half years should be as general as possible, and the student given a broad foundational and cultural knowledge. Suppose that the graduate, after having specialised in, say, forest entomology, finds it impossible, on graduation, to obtain employment in his chosen field. He has to find something to do. If he waits for a government appointment as an entomologist, he may have to wait for years. He finds that there is an opening available as a lumber salesman. He feels that he has an aptitude for such work, but has, unfortunately, never taken any courses in salesmanship, argumentation, business correspondence, accountancy, or in economics. He has had plenty of courses in entomology, the entomology of America, Asia and Europe, in courses in biology, dendrology, botany, histology and zoology, but these are useless qualifications for the prospective job. $\mathrm{He}$ is, as a matter of fact, little better equipped to fill this position than an untrained high school graduate. $\mathrm{He}$ decides to wait, therefore, until an opportunity arises such as he desires and has been trained for, accepting meanwhile some minor job for bread and butter purposes, really the only alternative he has. And the opportunity never arises! He remains permanently divorced from the forestry profession, remains disgruntled for the rest of his life, and reflects that he might have saved himself much time and money if he had never taken a forestry course. This is a tragedy which has befallen many graduates: yes, and many, also, who have taken post-graduate degrees!

Another personal disability due to over-specialisation is the fact that, although intensive training in specialised subjects may fit a man for a particular job, it leaves him with little qualification to act as an executive or administrative head. The aim' of a college of forestry should be to turn out potential leaders, as well as skilled workers. If it is not, then the future of the profession of forestry as a whole is indeed dark. You can do greater service to the forestry profession and to each individual graduate by giving him a broad training, under the assumption that some day he will become a leader, and then securing for him a position where he can learn a junior specialised job, with the assurance that his fundamental training will enable him to master it rapidly, and that his superiors, through observation, will direct his promotional steps in the way best suited to his capabilities, than by training a man intensively in one particular subject.

Let us suppose, again, that a man has been trained in this way during his 
undergraduate years, that he extends his specialisation into post-graduate courses, as far as a doctor's degree, and that he is successful in obtaining a position in his chosen niche. He will find that he generally has to accept a small salary, at least at the start, and his position is usually subordinate or junior, where he often has to unlearn much of what he was taught at college. The monetary outlay and the time spent in such training are out of all proportion to the pecuniary dividends which the graduate can usually hope to gain. And pecuniary dividends are what the student largely has in view during his college career. The advancement of the forestry profession, improving the condition of our woodlands, sentimental ideas of saving our noble forest heritage from fire, from the axe, for the benefit of posterity, are noble ideals, doubtless, but they provide propaganda which are suitable only for Boy Scouts, Girl Guides, and so forth, and the average undergraduate does not study for four or five years solely in order to pursue such sentimental chimerae. His chief interest is in making a living. If it is not during his early years, it becomes so later on, when a wife and family make increasing demands upon his purse.

I do not subscribe to the common concept that the function of a forestry school is to turn out wiseacres to whom the whole world of forestry and its associated sciences is an open book. It should be the function of his employers, whether government departments, private institutions, corporations, or individuals, to train the man after he has left college. They should not expect him to be a Delphic oracle, able to supply solutions to all troublesome questions which may come up from time to time, a compendium of knowledge whose brains may be picked at will in consideration of a small monthly stipend. When the oracle does not function as expected, they should not feel at liberty, as they often do, to condemn the college of forestry and the educational system which evolved such an unsatisfactory product. In other words, I object to the exploiting of the college graduate. I can only object in theory, and I suspect that my voice is as one crying in the wilderness, since the economic system of the times seems to demand that graduates continue to offer themselves in large numbers as sacrifices on the altar of specialism. Nevertheless, the colleges themselves are in a position to do much to reduce the casualty lists.

Although the current demand is for specialists, college-trained, as against those trained by experience, the colleges of forestry should in fairness refrain from leading the student astray by dangling the lure of specialism and a large salary before his nose, before the unfortunate man has had time to orientate himself. Give him a chance to obtain the equipment wherewithal he may be in a position to assess the possibilities which are open to him. Give him a chance to learn his limitations, before he commits himself to a course whch he may regret. That can be done by making him curb his impatience to ob- 
tain a place in the sun, and making him adhere to a rigidly foundational, broad training in his first two years and a half of college life. He will thank you later on.

There are one or two remarks I would make upon the teaching of certain subjects in the forestry curriculum. Firstly the teaching of English.

More attention than is the rule should be paid to the teaching of English composition, and to a certain extent, public speaking. It has been my ex. perience that many forestry graduates, individually clever and earnest work. ers, carry little weight in the communities where they live, and suffer from the point of view of efficiency in their work, simply because they are quite inarticulate and cannot express themselves adequately either on paper or by word of mouth. I have encountered graduates, not only in forestry, but in other sciences, who are not only unable to write a decent piece of English composition, but are deplorably weak in orthography. I have known other graduates who were unable to obtain employment simply because they were unable to write a good letter of application.

A knowledge of foreign languages is a great help, particularly if the student expects to carry on research work, but a knowledge of his mother tongue is of far greater importance. A sound knowledge of the English language, written and spoken, is essential to a man nowadays who expects to become a leader. The good training which comes from debate is also important.

I have found this a weak point in the training of graduates from Canadian universities, and particularly in the training of those from American universities. A man should be able to express his ideas well, no matter whether he gravitates into government service, into research work, or into engineering or commercial practice. In any of these fields he is handicapped if he does not have a good knowledge of the English language. The fault may be in the elementary and high schools. I do not know. But an attempt should be made to remedy the omission as soon as the student reaches the university. Foresters who cannot speak well, nor write a good report or business letter can never expect to carry much weight.

The curricula of some forestry colleges is top-heavy with courses in forest management, forest regulation, forest finance, forest administration, and in the study of various silvicultural systems. Some such courses are needed by those who expect to enter government forestry services, but not to such an extent as they are usually given. Some of these courses could be covered in spare time reading. They are often tedious, attenuated, over padded and vague, and altogether are invested with too much importance. Few students take them seriously. The time has gone by when colleges of forestry turned out only forest rangers. The scope and dignity of the profession of forestry have been extended by the application of its graduates to laboratory and field research in forest products and the standing tree, the pulp and paper indus- 
try, logging engineering, the manufacture and utilisation of forest products, and the marketing of same. To replace some of these silvicultural courses are needed business management, economics, salesmanship, foreign trade, business law.

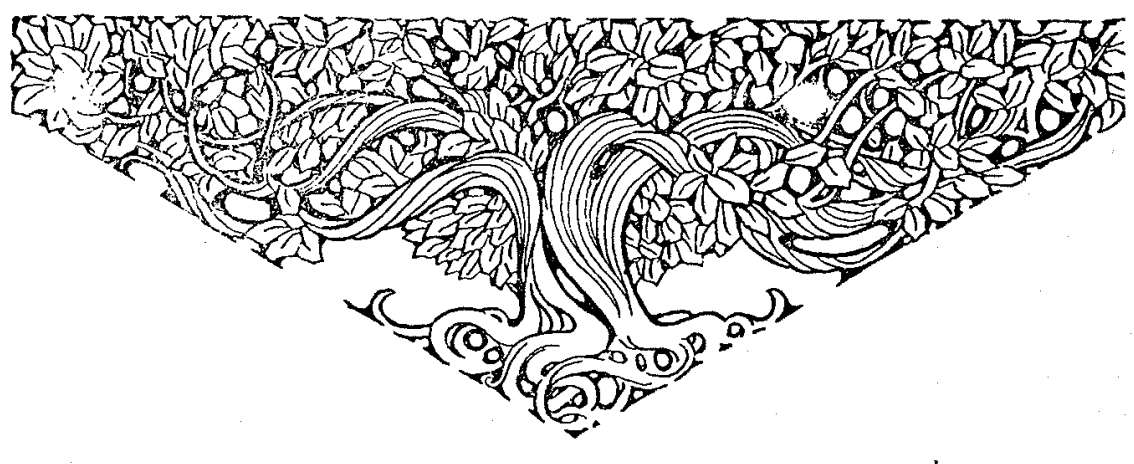

